\title{
Sustainable household egg production to enhance household food security
}

\author{
R.G. MacGregor and L. Abrams \\ Department of Animal Health and Production, Faculty of Veterinary Science, Medical University of Southern Africa, \\ P.O.Medunsa, 0204 Republic of South Africa
}

Received 6 May 1996; accepted 6 January 1997

\begin{abstract}
A simple method of keeping laying hens has been developed with the aim of improving family nutrition through the provision of high quality egg protein at low cost. A unit is kept at a family's home and provides on average six eggs per day for daily household consumption after a number of eggs have been sold to cover the daily cost of feeding the hens. Hens are purchased at point of lay and are kept for 52 weeks during which time they would lay approximately 260 eggs under natural light. They are then sold for human consumption and the money used to purchase new point of lay pullets. The scheme is sustainable requiring no additional capital outlay, has a positive effect on household food security and could probably be successfully replicated in other African countries.

'n Eenvoudige metode om lêhenne aan te hou met die doel om voeding van 'n gesin te verbeter deur die verskaffing van höe kwaliteit eierproteien teen lae koste, is ontwikkel. ' $n$ Eenheid word by die gesinshuis gehou en verskaf gemiddeld ses eiers per dag vir daaglikse menslike gebruik nadat 'n sekere hoeveelheid eiers verkoop is om die daaglikse voerkoste van die henne te dek. Henne word op punt van lê aangekoop en vir 52 weke aangehou, waartydens hulle ongeveer 260 eiers in natuurlike lig lê. Hulle word daarna vir menslike gebruik verkoop en die geld word vir die annkope van nuwe punt van lê henne gebruik. Die skema is lewensvatbaar, benodig geen addisionele kapitaal nie, het 'n positiewe effek op gesinsvoedselsekuriteit en kan moontlik suksesvol in ander Afrika-lande gedupliseer word.
\end{abstract}

Keywords: household egg production, food security

\section{Introduction}

A simple method of keeping poultry for egg production by resource-poor rural households has been developed in response to the critical nutritional deficiencies in the black population of Southern Africa, the poor economic environment and a demand for information and assistance by various interested communities in Southern Africa.

In $1990,83 \%$ of black households living in rural areas and the homelands lived below the bread line (Absa Bank, 1993). Further the prevalence of malnutrition in children under the age of five years over the period of 1980 to 1990 was in the order of $42 \%$ (Absa Bank, 1993). Protein malnutrition may be addressed by the provision of high quality protein to the existing high energy maize diet. Eggs are a source of high quality protein as indicated by the requirements of infants, children and adults and the reported protein composition of eggs (Lunven et al., 1972) in Table 1.

This project began in January 1992 with the aim of improving family nutrition through the provision of high quality egg protein at low cost. To date over 4000 individual household units have been established, of which 2500 have successfully been in operation for more than one year. To date the units have been concentrated mainly in the Northern Province (Regions 3, 1,2) formerly known as Gazankulu, Lebowa and Venda with smaller numbers spread throughout the country.

\section{The Unit}

The unit consists of 12 commercially available laying hens accommodated in a cage which is attached to the wall of a
Table 1 Amino acid requirements of infants (older than six months), children and adults ${ }^{1}$ and amino acid composition of eggs (mg per $\mathrm{g}$ of protein)

\begin{tabular}{lcccc}
\hline Amino acid & Infant & $\begin{array}{c}\text { Child } \\
(10-12 \text { yrs })\end{array}$ & Adult & $\begin{array}{c}\text { Reported egg } \\
\text { composition }\end{array}$ \\
\hline Histidine & 14 & - & - & 22 \\
Isoleucine & 35 & 37 & 18 & 54 \\
Leucine & 80 & 56 & 25 & 86 \\
Lysine & 52 & 75 & 22 & 70 \\
Methionine & 29 & 34 & 24 & 57 \\
+ Cystine & & & & \\
Phenylalanine & 63 & 34 & 25 & 93 \\
+ Tyrosine & & & & \\
Threonine & 44 & 44 & 13 & 47 \\
Tryptophan & 8.5 & 4.6 & 6.5 & 17 \\
Valine & 47 & 41 & 18 & 66 \\
\hline
\end{tabular}

'World Health Organisation

house, hut or building or alternatively the cage is raised off the ground on bricks or a wooden frame. The cages are made using commercially available weldmesh and have the following dimensions: $1,2 \mathrm{~m}$ long, $0,70 \mathrm{~m}$ wide and $0,40 \mathrm{~m}$ high. The cage is divided into three sections, each containing four hens. Water is provided by means of drinking nipples attached to inverted $2 \ell$ cooldrink bottles.

The 12 hens produce approximately 10 eggs per day for the 
majority of the production cycle under natural light and when fed a commercially available balanced feed. The average egg production for the unit over the entire laying cycle is approximately nine eggs per day.

\section{The Hens}

Use is made of the best commercially available laying hens which are purchased when they are sexually mature at 20 to 22 weeks of age. They are kept for one laying season only (52 weeks), after which they are sold for human consumption. A hen has a potential to lay approximately 280 eggs per year when receiving $16 \mathrm{~h}$ light per day. The majority of people with whom we are working, however, do not have electricity and hence the extension of the natural day length to the optimum of $16 \mathrm{~h}$ per day is not possible. We have found, however, that provided the unit is situated so as to make maximum use of natural daylight, the long natural summer day length is sufficient to stimulate the hens to produce approximately 250 to 260 eggs per hen per year.

Commercial breeds of hens available in South Africa and which have been used in this project are the following: Hyline Silver and Brown, Amberlink and the Lowman Brown.

\section{Feeding}

The hens are fed commercially available specially formulated and balanced feed called 'all mash laying mash' which has a $16 \%$ protein content. The hens will consume between 110 to $120 \mathrm{~g}$ of feed per day. The correct feed is absolutely essential to achieve maximum egg production. Use of any other feed will not be economical as egg production will decrease significantly. The feed is readily available in all parts of Southern Africa, since feed manufacturers selling maize meal for human consumption also sell 'all mash laying mash'.

\section{Economics}

Point-of-lay pullets are bought, kept for one laying season and then sold at a price similar to which they were purchased. For example, in 1992, point-of-lay pullets purchased in January cost R10,50 each and were sold in December, after laying approximately 250 eggs, at R14,00 each. New point-of-lay pullets to restock the cage for the next year (1993), cost R13,00 each. Thus the costs of restocking the cage with new point-of-lay pullets is covered by the sale of cull hens. If the hens were not sold at the end of the laying season they would begin to moult approximately 60 weeks after assuming production and during this time they would consume feed but lay no eggs. The moult would last for two to three months depending on certain conditions. The hens would then resume production but the quality of the eggs in terms of shell quality and production would be inferior to the first season of production. It thus makes economic sense to sell the hens after one season's production.

To cover the daily feed costs of the hens, four eggs are sold at approximately $40 \mathrm{c}$ each to friends and neighbours, leaving six eggs for daily household consumption. The money derived from daily egg sales is saved to purchase the next bag of feed at the end of the month thus making the unit self sufficient and sustainable.

The total cost of establishing a 12 hen unit is as follows (April
1996 prices):

\begin{tabular}{lc} 
Cage & $\mathrm{R} 100,00$ \\
Point-of-lay pullets $\times 12 @$ R16 each & 192,00 \\
Bag of feed $-50 \mathrm{~kg}$ & 58,00 \\
\cline { 2 - 2 } Total & $\mathrm{R} 352,00$ \\
\hline
\end{tabular}

\section{Implementation}

The concept of the scheme is presented to communities by means of oral presentations which include a demonstration held in their area. A demonstration unit is then established with a community appointed leader (called a key motivator) enabling the people to see the unit 'in action' and at their own leisure. This enables people to make an informed decision whether to participate. Individuals wishing to participate then submit their names to the key motivator who in turn informs us of the number interested. We then assist the communities in obtaining cages, hens and feed. Aarker (1994) states that those involved in agricultural development should not make decisions for those being assisted but rather expand the range of choices and knowledge available to the farmer for making decisions.

In implementing the units financial assistance has been made available to individual families. This assistance is available only when embarking on the scheme for the first time and for one unit only. Financial assistance has been made available to ensure those in greatest need are able to benefit from this project. Individuals receiving financial assistance are required to pay half the total cost of the unit in order to receive the unit with the balance being paid off over a number of months. Financial assistance is available to everyone in a community, but individuals are encouraged to pay the full cost as soon as possible so that the money may be used to assist other interested families. In some cases certain communities have purchased their units fully and have not made use of our finance.

Critical factors involved in the implementation of units will be discussed in a later paper.

\section{Success}

Information received on the actual success of the scheme on the ground has been derived by means of informal surveys. In 1993 , a survey was conducted of $25 \%$ of the 1042 units established in 1992 in five districts of Gazankulu. From the survey it was found that the participants situated furthest from the main centre (Giyani) had the most difficulty in obtaining feed and paid much higher prices than those participants in and around Giyani (Table 2). In this particular district (Mala) 18\% of participants decided not to continue with the scheme, since the cost of the feed was too high and the feed was too difficult to obtain. They had thus made an economic decision about their unit. Rhoades (1990) and Aarker (1994) state the importance of respecting the knowledge of those being assisted and realizing that they are capable of making their own decisions since they know and understand their own unique conditions better than any outsider. Chambers (1991) discusses the limitations of conducting questionares as the sole source of information gathering in rural communities and suggests the use of the Rapid Rural Appraisal technique.

Another possible indicator of the success of the scheme has 
Table 2 Per cent of participants not continuing with the scheme based on district, distance from Giyani and cost of feed

\begin{tabular}{lccc}
\hline District & $\begin{array}{c}\text { Distance from } \\
\text { Giyani }(\mathrm{km})\end{array}$ & Cost of feed $^{1}$ & $\begin{array}{r}\text { Per cent which } \\
\text { did not continue }\end{array}$ \\
\hline Giyani & 0 & 48,50 & 0 \\
Malemulele & 30 & 48,50 & 10 \\
Rietavi & 50 & 51,53 & 2 \\
Hlanganani & 25 & & - \\
Mala & 300 & 54,56 & 18 \\
\hline Cost of feed in 1992 for $50 \mathrm{~kg}$ & & \\
2 Of the percentage interviewed &
\end{tabular}

been the relatively high adoption rate of approximately 900 units per year between 1992 and 1995. However, the measure which could be the best indication of the success of the scheme is that a high percentage of participants have continued with this scheme for more tinan one laying season. At the end of the laying season the participant has to dispose of the cull hens and purchase new point of lay pullets (having ordered them a few months in advance) to ensure continued egg production. This requires considerable time and effort and may be a measure of the individual's commitment. It is important in the evaluation of any project that the success is measured in terms of what the participants consider important (Chambers, 1991).

\section{Discussion}

This article describes the project in general and how it has been implemented throughout the various areas. This project has identified numerous aspects requiring further scientific research such as the quantification of egg production under natural light and its variation in the different climatic regions of the country. The discussions of various authors (Norman \& Krishnaswamy, 1978; Low, 1986) with respect to the approach of small scale farmers to new technologies in various areas of the world are noted, but better characterisation of our target group using methods like Rapid Rural Appraisal and the assistance of sociologists is required. Much of our work has been driven by the demand of individuals and communities for such systems as described after having seen or heard of existing units. Results from field workers are that the scheme has made eggs available to many rural children who relish the eggs (Malephane et al., 1993). Malephane reports further that some participants are considering expanding the number of hens kept (Malephane et al., 1993).

Johnson et al. (1996) reports of a very similar study in the rural areas of Guatemala with the same aim of improving family nutrition. During the period from 1992 to the end of
1995, 137 families were participating in the scheme, with 61 families keeping laying hens and the balance raising broilers. Johnson et al. (1996) reports that the raising of poultry met both their objectives of improving nutrition and providing additional income. Further, they report that of the eggs produced $30 \%$ are consumed by the family and $70 \%$ are sold unlike in our scheme were generally $60 \%$ are consumed and $40 \%$ are sold.

\section{Conclusions}

Household egg production as described above is a viable method of improving the nutritional status of impoverished rural families in Southern Africa.

The project is sustainable and requires no additional capital outlay.

The project contributes positively to household food security. This project could probably be successfully replicated in other African countries.

\section{References}

AARKER, J., 1994. Livestock for a small earth. Seven Locks Press. Washington.

ABSA BANK, 1993. Economic Spotlight -- The structure of the South African Economy. No. 7. July.

CHAMBERS, R., 1991. Rural development - putting the last first. Longman, England.

JOHNSON, N.P., FLORES, M.Q.. GUZMAN, V.H. \& DAVILA. H., 1996. Establishing broiler and layer enterprises in rural Guatemala. Proceedings of the XX World's Poultry Congress. Vol III, page 311, New Delhi, 2-5 September.

LOW, A., 1986. Agricultural development in Southern Africa: farm household economics and the food crises. ISBN 0-85255-102-9.

LUNVEN, P., Le CLEMENT de ST MARCQ, C.. CARNOVALE, E. \& FRATONI, A. (1972). Unpublished data, Nutrition Division of FAO \& National Nutrition Institute. Rome.

MALEPHANE, A.H., MACGRLGOR, R.G., NGATSANE, I. \& ABRAMS, L., 1993. Medunsa Poultry Outreach Scheme - a Gazankulu case study. Proceedings of the Developing Areas Branch of the S A Society of Animal Science, Eiland Resort, Northern Province, 11-14 October.

NORMAN, D.W. \& KRISHNASWAMY, M.S., 1978. The adoption of improved technology by the small scale farmer. In: food enough for starvation for millions. Editor: D. Ensminger, McGraw Hill Publishers. New Delhi.

RHOADES, 1990. The role of farmers in the creation of agricultural technology. In: Farmer first. Editors: R.Chambers, A.Pacey \& L.A. Thrupp. Intermediate Technology Publications, London.

WORLD HEALTH ORGANISATION, 1971. Energy and protein requirements. Report of the joint $\mathrm{FAO} / \mathrm{WHO}$ ad hoc expert committee. World Health Organisation Technical Report Series No.522. 